\title{
Coping with aquatic hypoxia: how the plainfin midshipman (Porichthys notatus) tolerates the intertidal zone
}

\author{
Paul M. Craig • John L. Fitzpatrick • Patrick J. Walsh • \\ Chris M. Wood • Grant B. McClelland
}

Received: 26 November 2012 / Accepted: 25 March 2013 /Published online: 7 April 2013

(C) Springer Science+Business Media Dordrecht 2013

\begin{abstract}
Although plainfin midshipman (Porichthys notatus) are primarily known for their alternative reproductive tactics, and the dimorphic male subtypes, in which Type-I males demonstrate parental investment and mate attraction, and Type-II males 'sneak' fertilization and show no investment after fertilization, little is known about the physiology and tolerance to low aquatic oxygen while nesting in the intertidal zone. In May 2007, females and Type-I and Type-II males were collected, and in June 2009, only Type-I males were collected from nest sites on the coast of Vancouver Island, British Columbia. In the 2007 season, an initial assessment of hypoxia tolerance and nest parameters was recorded for the three subtypes of midshipman. Historical evidence indicates that Type-I males remain on the nest for prolonged periods,
\end{abstract}

P. M. Craig • J. L. Fitzpatrick • C. M. Wood •

G. B. McClelland

Department of Biology, McMaster University,

1280 Main St W,

Hamilton, Ontario, Canada L8S 4K1

\section{P. J. Walsh}

Department of Biology, University of Ottawa,

30 Marie Curie,

Ottawa, Ontario, Canada K1N 6N5

P. M. Craig • J. L. Fitzpatrick • P. J. Walsh • C. M. Wood •

G. B. McClelland

Bamfield Marine Sciences Centre,

100 Pachena Drive,

Bamfield, British Columbia, Canada V0R 1B0 and our results suggest they can cope with repeated bouts of aquatic hypoxia by elevating their hematocrit and tolerating high lactate levels. The 2009 season was directed at examining the aquatic hypoxia tolerance of only the Type-I male. Hypoxic ( $\sim 15 \%$ air saturated water) Type-I males had oxygen consumption rates at $\sim 12 \%$ of the normoxic control $(\sim 100 \%$ air saturated water) and a $\mathrm{P}_{\text {crit }}$, the critical oxygen tension, when a fish switches from oxyregulator to oxyconformer, could not be determined; an indication that these fish are solely oxyconformers. With prolonged exposure to aquatic hypoxia, Type-I males displayed significant elevations in plasma and tissue lactate (heart), tissue glucose (liver), and a depression in gill $\mathrm{Na}^{+} / \mathrm{K}^{+}$ATPase and catalase activities. Results suggest that male Type-I midshipman survival in the

\section{J. L. Fitzpatrick \\ Computational and Evolutionary Biology, \\ Faculty of Life Sciences, University of Manchester, Manchester M13 9PT, UK}

\author{
Present Address: \\ P. M. Craig $(\bowtie)$ \\ Department of Biology, University of Ottawa, \\ 30 Marie Curie, \\ Ottawa, Ontario, Canada K1N 6N5 \\ e-mail: pcraig@uottawa.ca
}


intertidal zone is enhanced by metabolic depression and tolerance to anaerobic byproducts.

Keywords Aquatic hypoxia - Plainfin midshipman . Marine $\cdot$ Intertidal

\section{Introduction}

Plainfin midshipman (Family Batrachoididae; Porichthys notatus Girard 1854) are distributed along a large ecological niche on the Pacific coast of North America, ranging from the Baja Peninsula to Alaska (Walker and Rosenblatt 1988). During the breeding season (May-August; Vancouver Island, BC), midshipman migrate from depth and take up residence in the intertidal zone where females are courted by vocalizations of males (called Type I males) who have established nest sites underneath large rocks (Arora 1948; Thompson et al. 1988; Bass et al. 1999). After male fertilization of the egg mass, the female departs the nest, leaving the Type I male to care for the eggs. Oviposition on the underside of intertidal rocks is key to the survival of the eggs and larvae during low tide and air emergence, and survivals is enhanced by the parental care of the male which consists of gentle fanning, cleaning the nest site, and hydrating the eggs if they dry during low tide (Arora 1948). Once hatched, the larvae remain attached to the underside of the rock by an adhesive disc, all while the Type I male remains on the nest to ensure safety for the larvae until they depart as juveniles, approximately 45 days post-fertilization (Arora 1948). Parental care in this taxon is unique, as the plainfin midshipman is the only known intertidal fish that provides care beyond the point of hatching (Coleman 1999). Interestingly, male midshipman fish are dimorphic. While Type-I males invests in vocalization for mate attraction, territorial defense, and parental care, another type of male that are much smaller in comparison, called Type-II males, may steal fertilization from Type-I males using female mimicry or sneaking behaviors (Brantley et al. 1993; Brantley and Bass 1994). Type-II males and females do not remain on the nest sites for long periods of time (Brantley and Bass 1994). Their reproductive behaviours have identified midshipman as a target for many studies directed at alternative reproductive tactics (e.g., Brantley and Bass 1994), but little is known regarding the basic physiology of these fish. More specifically, we are aware of no studies on the responses to aquatic hypoxia of the nesting Type-I males, who must remain on the nest site for extended periods of time.

Fish that reside in the intertidal zone are faced with the cyclic environmental stressor of hypoxia during the daily oscillations of the tide. Those that do not retreat with the receding waters of low tide are trapped in shallow pools that are invariably depleted of oxygen and need to invoke a variety of protective physiological or behavioral responses. This is especially true for the plainfin midshipman. During low tide, these fish (particularly the Type-I males) are often stranded in nests, which are found beneath large rocks in the intertidal flats, with significantly diminished dissolved oxygen levels (lowest personal observation: $2.5 \%$ air saturated water) or nests devoid of water (personal observation), for several hours where they must endure dramatic reductions in available oxygen content (Martin and Bridges 1999). Through a combination of the physicochemical properties of oxygen solubility in seawater, drastic temperature changes, decreases in $\mathrm{pH}$ and salinity in intertidal pools, organismal respiration and daytime photosynthesis, a rapid depletion of oxygen may occur once the tide has receded (Truchot and Duhamel-Jouve 1980; Bridges 1993).

Recently, Perry et al. (2010) examined the acidbase regulation of plainfin midshipman, and demonstrated that they have a well-developed ability to tolerate severe hypercapnic exposure $\left(5 \%\right.$ water $\left.\mathrm{CO}_{2}\right)$, which also may occur in the aquatic environment of nesting fish. This is accomplished by increasing plasma $\mathrm{HCO}_{3}{ }^{-}$, although clearance of $\mathrm{HCO}_{3}{ }^{-}$when returned to normocapnia $\left(<0.1 \%\right.$ water $\left.\mathrm{CO}_{2}\right)$ was rather slow, possibly the consequence of an aglomerular kidney (McDonald and Walsh 2007). In addition, we have documented that the sperm of this species is well adapted to function under aquatic hypoxic conditions (Fitzpatrick et al. 2009). However, to date, no study has examined the physiology of the midshipman fish itself under aquatic hypoxia. The objectives of the present study are to make an initial assessment of the ability of the plainfin midshipman to tolerate daily bouts of aquatic hypoxia in the intertidal zone, with comparison made between females and Type II males. Additionally, Type-I males were collected and subjected to progressive hypoxia, and measurements of oxygen consumption were taken for identification of midshipman being either an 
oxyregulator (constant respiratory rate under declining water oxygen tensions) or oxyconformer (respiratory rate declines in parallel with reduced oxygen tensions). Further analysis of plasma, tissue metabolites, and enzyme activities were taken to measure their tolerance of anaerobic by-products.

\section{Materials and methods}

Field data

Field collection Plainfin midshipman were collected from nest sites on Vancouver Island, British Columbia, under permits from the Department of Fisheries and Oceans, Canada. All experiments were conducted under protocols approved by the McMaster University Animal Research Ethics Board and conform to the principles of the Canadian Council for Animal Care. To avoid impacts on the population, numbers were kept to a minimum while retaining statistical power. Collections of both sexes were first made during low tide in late May of 2007 from Mill Bay $\left(48^{\circ} 63 \mathrm{~N}\right.$, $123^{\circ} 53^{\prime} \mathrm{W}$ ) for field measurements of hematocrit (Hct) and plasma lactate (Type-I males, $n=11,216.6 \pm 34.3 \mathrm{~g}$; females, $n=12,120 \pm 17.3 \mathrm{~g}$; Type-II males, $n=7,80.5 \pm$ $12.8 \mathrm{~g}$ ). Male morphs were determined based on behavioural observations in the field (only Type I males guard nests), body size and morphological differences, which included extreme differences in body mass and length (see Brantley and Bass 1994), differences in gonadosomatic index and presence of a large sonic muscle in Type-I males. Upon capture from nests, a caudal blood sample was taken and centrifuged immediately for Hct and plasma was stored in liquid nitrogen for later analysis of lactate. In early June of 2009 only Type-I males $(n=16$; $171.1 \pm 15.8 \mathrm{~g}$, morph determined as outlined above) were collected from Nanoose Bay $\left(49^{\circ} 15^{\prime} \mathrm{N}, 124^{\circ} 10^{\prime} \mathrm{W}\right)$ for laboratory experimentation of progressive hypoxia. Nest site parameters (temperature, $\mathrm{pH}$, dissolved $\mathrm{O}_{2}$ ) were recorded during the peak of low tide (June 6th 2009, 11:40 am) using a calibrated-handheld Accumet $\mathrm{pH} /$ dissolved oxygen meter (Fisher Scientific). Additional water samples were taken for measurement of urea and ammonia, which were quantified using the diacetyl monoxime method of Rahmatullah and Boyde (1980) and indophenol blue method of Ivancic and Degobbis (1984), respectively. Fish were transported in aerated seawater baths and housed at Bamfield Marine Sciences Centre in aerated tanks $\left(10{ }^{\circ} \mathrm{C}\right)$ with a continuous renewal of fresh seawater that was pumped directly from Bamfield Inlet into the holding tanks. Tanks $[0.25 \mathrm{~m}(\mathrm{~h}) \times 0.6 \mathrm{~m} \mathrm{(w)} \times 2.5 \mathrm{~m}(\mathrm{l})]$ were supplied with large rocks and PVC piping which provided shelter, in addition to a large tarpaulin that covered the tanks to minimize disturbance. These animals were not fed during the duration of the experiments, as Type-I males do not feed while on the nest, and therefore fast during the period of parental care (Coleman 1999). Fish were housed for a period of 1 week prior to experimentation.

\section{Laboratory data}

Progressive hypoxia Individual fish (Type-I males) were placed in darkened 1.5-L Mason jars (1.4 L water) and allowed to adjust for $1 \mathrm{~h}$ with a continuous flow of normoxic seawater. Seawater flow was stopped and the jars were sealed with a modified rubber stopper. All jars were bathed in free-flowing $10{ }^{\circ} \mathrm{C}$ seawater, to keep temperature within the jars constant. An initial $0.5-\mathrm{mL}$ water sample and additional $0.5-\mathrm{mL}$ samples were taken every $30 \mathrm{~min}$ for a total exposure time of $3 \mathrm{~h}$ through the rubber stopper using a $1-\mathrm{mL}$ syringe. Water oxygen tension was determined immediately after sampling using a Radiometer-Copenhagen $\mathrm{O}_{2}$ electrode maintained at experimental temperature. Oxygen consumption rates $\left(\mathrm{MO}_{2}\right)$ were determined over each $30 \mathrm{~min}$ period according to the change in the dissolved oxygen in the chamber multiplied by the water volume, and expressed relative to the body mass of the fish. $\mathrm{P}_{\text {crit }}$, or the critical oxygen tension at which the fish is considered an oxyconformer, was determined using the least squares regression method outlined by Hastings and Burggren (1995), based on the computer model described by Yeager and Ultsch (1989).

Hypoxic exposure and tissue sampling After a week of recovery in their normoxic holding tanks, the Type-I males, which had been used for the progressive hypoxia experiment, were now employed for an assessment of tissue metabolites during hypoxia. These fish were placed in $6 \mathrm{~L}$ of seawater in polyethylene Omni Boxes $^{\mathrm{TM}}$ (Canadian Tire Corp, Canada) bubbled with either air (normoxic, $100 \%$ air saturated water; $n=8$ ) or nitrogen (hypoxic, $15 \%$ air saturated water; $n=8$ ) for 
$4 \mathrm{~h}$ to simulate intertidal oxygen deprivation (Table 1). The Omni Boxes ${ }^{\mathrm{TM}}$ were bathed in a continuous flow of seawater to ensure temperature was maintained at approximately $10^{\circ} \mathrm{C}$. At the end of the exposure, fish were removed and terminally anesthetized rapidly with a lethal overdose of tricaine methanesulfonate $(1.0 \mathrm{~g} / \mathrm{L}$ MS-222, Sigma; neutralized with $1.0 \mathrm{~g} / \mathrm{L} \mathrm{NaHCO}_{3}$ ), immediately followed by a caudal blood sample for measurements of Hct and lactate, and tissue harvesting of gill, liver and heart, which were rinsed with saline to removed residual blood, and freeze-clamped in liquid nitrogen for later analysis of metabolite concentrations and enzyme activities.

Enzymatic and metabolite assays Unless noted, all chemicals and reagents were purchased through Sigma (St Louis, USA). Heart, liver, and gill from normoxia and hypoxia exposed fish were powdered using a liquid nitrogen-cooled motor and pestle for measurements of tissue glucose, glycogen and lactate. Powdered tissues were weighed, freeze-dried over night (Labconco Freeze dry systems), and $50 \mathrm{mg}$ of dried-powdered tissue was then homogenized in 20times of volume extraction buffer containing $20 \mathrm{mM}$ Hepes (pH 7.0), 1 mM EDTA, and 0.1\% Triton X-100 for quantification of enzymatic activity in the liver and gill. Samples for tissue metabolites (glucose, glycogen, and lactate) where homogenized in 2 volumes $8 \%$ perchloric acid containing $1 \mathrm{mM}$ EDTA, and samples were split and neutralized with either $2 \mathrm{M}$ $\mathrm{KOH}$ for lactate or $3 \mathrm{M} \mathrm{K}_{2} \mathrm{CO}_{3}$ for glucose and glycogen samples. Tissue glucose, glycogen, lactate and plasma lactate were measured at $340 \mathrm{~nm}$ following standard spectrophotometric protocols (Bergmeyer 1983). For enzyme assays, gill and liver tissues were homogenized in ice-cold $50 \mathrm{mM}$ phosphate buffer (50 mM KH $\mathrm{PO}_{4}, 50 \mathrm{mM} \mathrm{K} \mathrm{HPO}_{4}$ ), containing $1 \mathrm{mM}$ EDTA, pH 6.7. Catalase (CAT) activity was assayed at $28{ }^{\circ} \mathrm{C}$ using a modified method based on Clairborne (1985). The reaction buffer consisted of $20 \mathrm{mM}$ potassium phosphate, $\mathrm{pH} 7.0$, and $20 \mathrm{mM}$ $\mathrm{H}_{2} \mathrm{O}_{2}$. The reaction was recorded as the decomposition of $\mathrm{H}_{2} \mathrm{O}_{2}$ at $240 \mathrm{~nm}$ over $1 \mathrm{~min}$. Protein concentrations for all samples were determined using BioRad kit reagents following the Bradford (1976) protocol using bovine serum albumin as a standard. Tissue $\mathrm{Na}^{+} / \mathrm{K}^{+}$ATPase activity (NKA) was determined using the microassay method of McCormick (1993). All samples were homogenized in SEI buffer $(150 \mathrm{mM}$ sucrose, $10 \mathrm{mM}$ EDTA, $50 \mathrm{mM}$ imidazole, $\mathrm{pH}$ 7.3) containing $0.3 \% \mathrm{Na}$ deoxycholic acid, which acts as an ionic detergent in the cell lysis buffer for membrane bound protein isolation. All assays were run in 96-well format on a SpectraMAX Plus 384 microplate reader using SOFTmax software 4.6 (Molecular Devices, Menlo Park, CA).

Statistical analysis Data have been expressed as mean \pm S.E.M. A one-way ANOVA was used to ascertain the overall differences for Hct and plasma lactate from field samples, with a Student-Newman-Keuls (SNK) post hoc test for all pairwise comparisons. A repeated measure ANOVA on ranks was used to assess the overall differences during progressive hypoxia, as normality assessment failed, with a Holm-Sidak post hoc test for pairwise comparisons to the normoxic control. A Student's $t$-test was used for all other pairwise analysis. All statistical analyses were performed using Sigma Stat (v3.1, Systat Software, Inc.) with a significance level of $p<0.05$.

\section{Results}

Nest parameters Dissolved oxygen levels recorded during the peak of low tide from nest sites $(n=8)$ found in Nanoose Bay in 2009 were $85 \%$ lower than open water values (Table 1), which gave us an estimate of the maximum average depletion of oxygen in the nests to use as laboratory conditions for further hypoxic experiments (see below). Along with reductions in dissolved oxygen there was a significant $\sim 4$-fold increase in water ammonia, and a $\sim 2$-fold increase in

Table 1 Water parameters of $\mathrm{pH}$, temperature $\left({ }^{\circ} \mathrm{C}\right)$, oxygen saturation $(\%)$, ammonia and urea $(\mu \mathrm{mol} / \mathrm{L})$ taken during the peak low tide $(11: 40 \mathrm{am})$ from midshipman nest sites $(n=16)$ on Nanoose Bay on June 6th, 2009

\begin{tabular}{lcr}
\hline Parameter & \multicolumn{1}{l}{ Nest } & Open water \\
\hline $\mathrm{pH}$ & $7.91 \pm 0.2^{*}$ & $8.45 \pm 0.1$ \\
${ }^{\circ} \mathrm{C}$ & $19.63 \pm 0.4$ & $19.6 \pm 1.2$ \\
Oxygen saturation (\%) & $14.5 \pm 4.1 *$ & $100 \pm 3.2$ \\
Ammonia & $14.98 \pm 1.9 *$ & $3.92 \pm 0.2$ \\
Urea & $14.81 \pm 7.1^{*}$ & $7.71 \pm 0.8$ \\
\hline
\end{tabular}

A * indicates a significant difference as compared to open water values taken for the intertidal zone at low tide on the same day $(p<0.05)$ 
water urea (Table 1). The seawater nest sites were slightly acidified, with a significant decrease in mean $\mathrm{pH}$ from 8.4 in open ocean waters to 7.9 (Table 1). It is noted that temperature in both the nests and adjacent bulk water of the embayment were significantly higher than historical seawater temperatures $\left(\sim 19^{\circ} \mathrm{C}\right.$ vs $\sim 10$ $\left.13^{\circ} \mathrm{C}\right)$ in the area, due to unseasonably warm $\left(28^{\circ} \mathrm{C}\right.$ air temperature) weather combined with a flat-graded intertidal zone (very shallow, without a sharp drop-off) which likely elevated the shore water temperature.

Enzymatic and metabolite response to hypoxia Field measurements of both hematocrit (ANOVA; $P=0.004$ ) and plasma lactate (ANOVA; $P=0.012$ ) were significantly lower in Type-II males (SNK for Hct: $P=0.004$; lactate: $P=0.018$ ) and females (SNK for Hct: $P=0.025$; lactate: $P=0.018$ ) than Type-I males (Fig. 1a). In a laboratory setting, there was an inverse relationship between ambient oxygen tension and both Hct $(P=$ $0.002)$ and lactate $(P<0.001)$ in midshipman exposed to normoxic $(95.7 \pm 3.0 \%$ air saturated water) or hypoxic $(14.5 \pm 2.9 \%$ air saturated water) conditions for $4 \mathrm{~h}$ (Fig. 1b). However, we did not observe the same absolute magnitude of plasma lactate increase in the laboratory as seen in the field data collected, as the mean plasma lactate in Type-I males exposed to hypoxia in the laboratory was less than $3.0 \mathrm{mmol} \mathrm{L}^{-1}$, or $\sim 6$-fold lower than values obtained from Type-I males in the field in 2007 (Fig. 1). Fish exposed to hypoxia in the laboratory showed no changes in tissue lactate in the liver or muscle, yet there was a significant 4fold increase in tissue lactate in the heart (Fig. 2a; $P=0.036)$. Note that these metabolite concentrations (Fig. 2) were expressed per unit-dry weight, whereas plasma lactate was expressed per unit
Fig. 1 a Hematocrit (\%) and plasma lactate $(\mathrm{mmol} / \mathrm{L})$ values from Type-I $(n=11)$, II $(n=7)$, and female $(n=12)$ midshipman fish collected in May 2007 at Mill Bay, Vancouver Island, British Columbia. b Hematocrit (\%) and plasma lactate values $(\mathrm{mmol} / \mathrm{L})$ from Type-I males collected June 2009 from Nanoose Bay and exposed to either normoxic $(\sim 100 \%$ air saturated water; $n=8)$ or hypoxic $(\sim 15 \%$ air saturated water, $n=8)$ conditions in the laboratory. Bars that do not share common letter are significantly different from each other
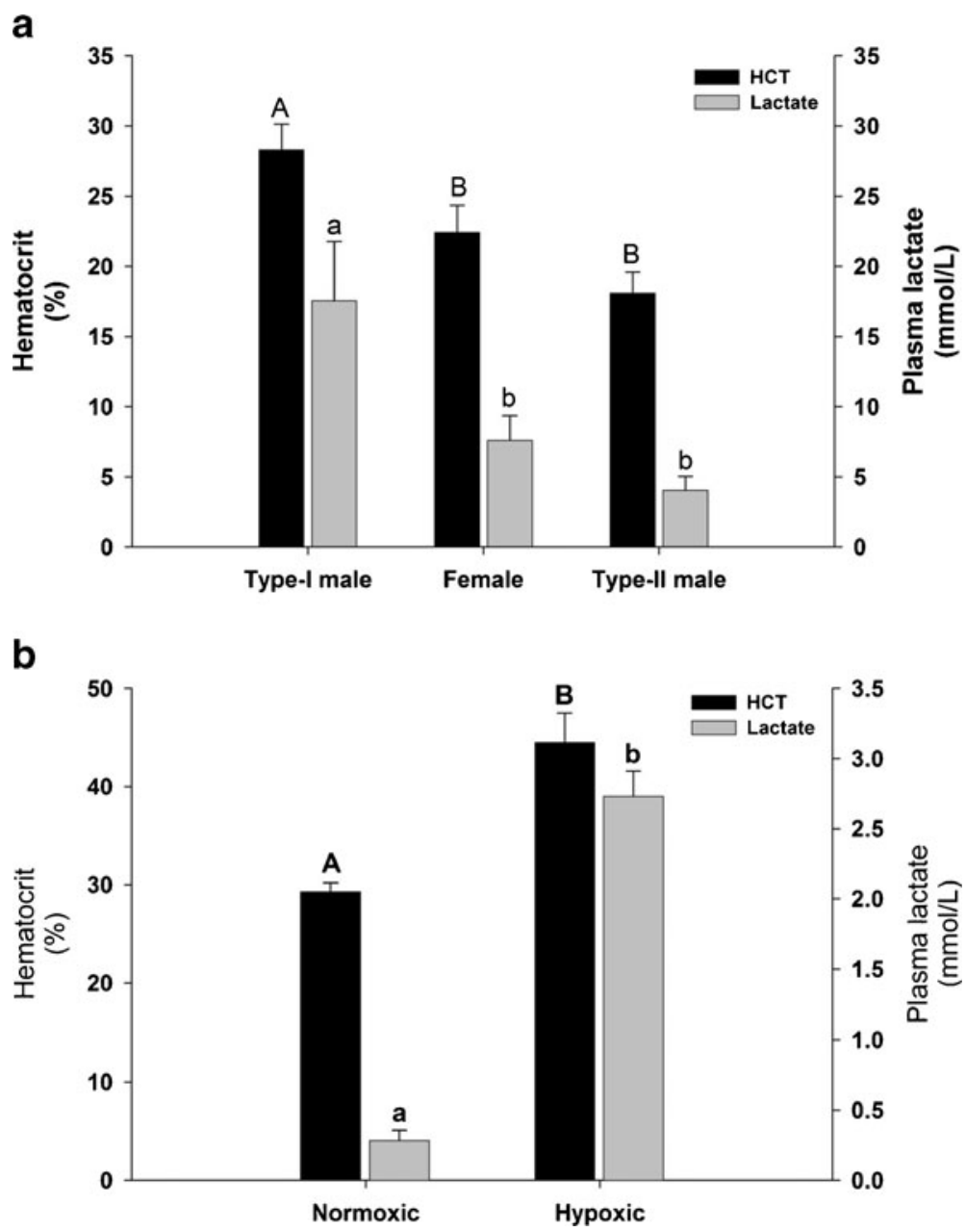
volume (Fig. 1). Although there were no changes in glycogen levels across all tissues, there was a 4.6-fold increase in liver glucose levels (Fig. 2b and c; $P<0.001)$. Measurements of catalase and

a

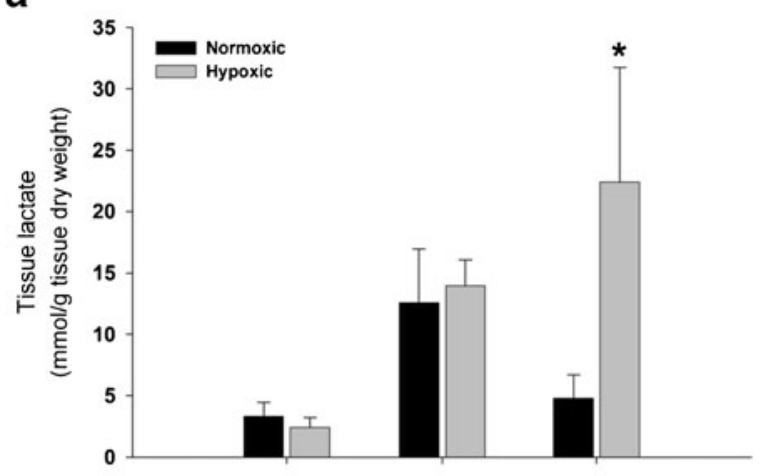

b

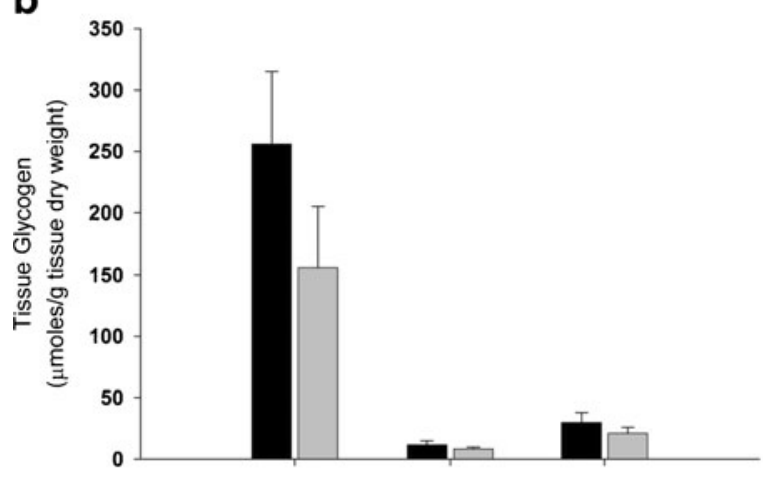

C

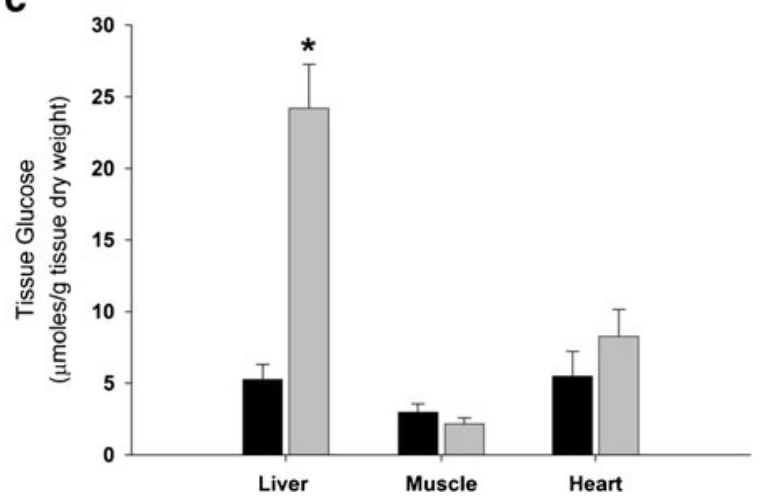

Fig. 2 a Liver, muscle, and heart tissue lactate ( $\mu \mathrm{mol} / \mathrm{g}$ tissue dry weight), b glycogen ( $\mu \mathrm{mol} / \mathrm{g}$ tissue dry weight), and $\mathbf{c}$ glucose $(\mu \mathrm{mol} / \mathrm{g}$ tissue dry weight) values taken from Type-I males collected June 2009 from Nanoose Bay exposed to either normoxic $(\sim 100 \%$ air saturated water; $n=8)$ or hypoxic $(\sim 15 \%$ air saturated water, $n=8)$ conditions in the laboratory. An asterisk indicates a significant difference between normoxic and hypoxic conditions within a tissue $(t$-test, $p<0.05)$
NKA activities were taken as indicator of cellular oxygen stress and energy consumption, respectively. Although there were no apparent changes for either enzyme in the liver of hypoxia-exposed fish, there were significant reductions in gill enzymatic activity for NKA ( $40 \%$; Fig. 3a; $P=0.032)$ and catalase $(\sim 50 \%$; Fig. $3 b ; P=0.047)$ in hypoxiaexposed fish compared to the normoxic controls.

Progressive hypoxia and metabolic rate Midshipman (Type-I males) significantly decreased overall oxygen consumption during progressive hypoxia in an oxyconformer fashion, as $\mathrm{P}_{\text {crit }}$ could not be determined for this species. Linear regression analysis revealed a significant positive relationship between water oxygen tension and oxygen consumption (Fig. 4. $\mathrm{R}^{2}=0.714, P<0.001$ ).

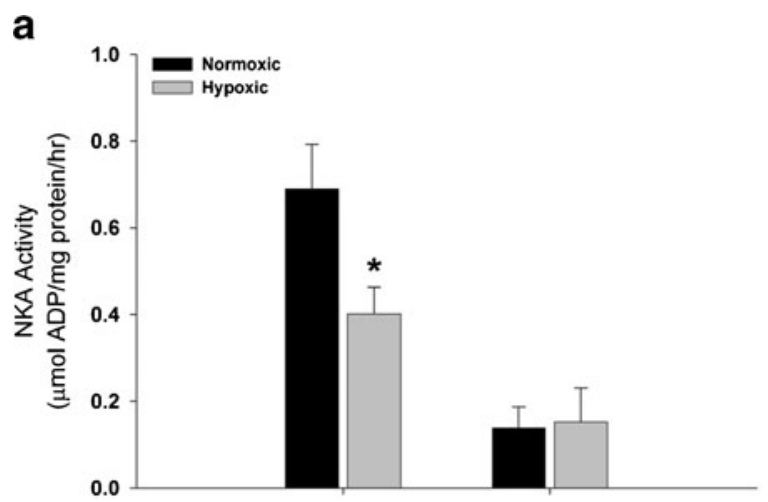

b

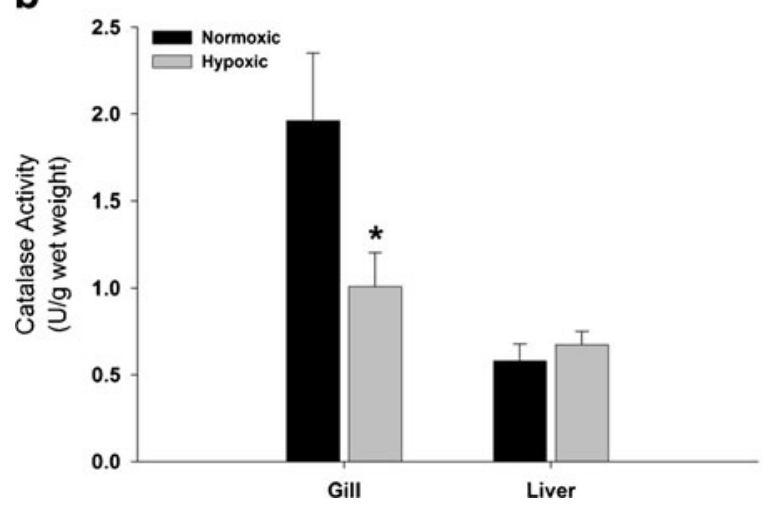

Fig. 3 a Enzyme activities levels for $\mathrm{Na}^{+} \mathrm{K}^{+}$ATPase and $\mathbf{b}$ catalase from gill and liver tissue sampled from Type-I males collected June 2009 from Nanoose Bay exposed to either normoxic $(\sim 100 \%$ air saturated water; $n=8)$ or hypoxic $(\sim 15 \%$ air saturated water, $n$ $=8$ ) conditions in the laboratory. An asterisk indicates a significant difference between normoxic and hypoxic conditions within a tissue $(t$-test, $p<0.05)$ 


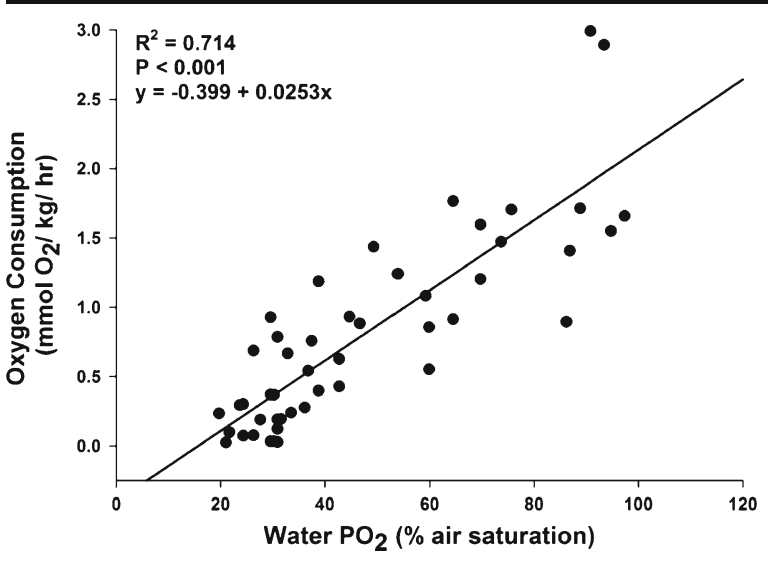

Fig. 4 The significant linear relationship between oxygen consumption versus \% air saturation in water of male Type-I midshipman during progressive hypoxia. Using the least squares regression method outlined by Hastings and Burggren (1995) a $\mathrm{P}_{\text {crit }}$ could not be determined and therefore these fish were identified as oxyconformers. $\left(\mathrm{R}^{2}=0.714 ; P<0.001\right)$

\section{Discussion}

This study provides unique insight into aquatic hypoxia tolerance associated with alternative reproductive tactics, as displayed through the differential buildup of anaerobic byproducts in females and male subtypes (Fig. 1a). Our results demonstrate the Type-I morph, the parental care provider, is able to survive extended (3-4 h) hypoxic conditions through increased anaerobic glycolysis (Fig. 2), metabolic suppression (Figs. 3 and 4), and tolerance to anaerobic byproducts (Fig. 1). Notably, these animals are fasting during this period of parental care, and all these responses must be superimposed on the responses to extended food deprivation. Evidence for this is the routine $\mathrm{MO}_{2}$ measured by Walsh et al (2001) in freshly trawled midshipman having an average oxygen consumption of $2.5 \mathrm{mmol} \mathrm{O}_{2} \mathrm{~kg}^{-1} \mathrm{~h}^{-1}$ vs the present study with $\sim 1.0 \mathrm{mmol} \mathrm{O}_{2} \mathrm{~kg}^{-1} \mathrm{~h}^{-1}$ (Fig. 4).

As first observed by Hubbs (1920) and later corroborated by Arora (1948), it is the Type I male midshipman who remains on the nest and provides parental care and protection to the developing embryos, only to leave once the juveniles are freeswimming. The females reside in the nest for only a short period of time, and vacate soon after oviposition takes place. Furthermore, there are two male morphs, Type-I males (who show parental investment) and Type-II ("sneakers" who show no investment after fertilization; Brantley et al. 1993;
Brantley and Bass 1994). Like the females, Type-II males tend to retreat from the nests once fertilization has occurred, as both are difficult to locate within a nest soon after the initiation of the breeding season (Fitzpatrick 2008). Early in the breeding season, many nest sites hold females and both male morphs, unlike later in the season when only Type-I males are on nest guarding developing embryos. Furthermore, from field samples taken in 2007, we demonstrated that the Type-I males have significantly higher values for both Hct and plasma lactate (Fig. 1a), likely due to the length of time the TypeI morph spent on the nest compared to the female and Type-II male. Increased Hct has been linearly associated with increased oxygen carrying capacity in some studies (Baldwin and Wells 1990; Sadler et al. 2000), and it has been suggested that changes in carrying capacity of blood are more important than alterations in blood oxygen affinity to deliver oxygen to tissues (Brauner and Wang 1997). It appears an initial physiological response to hypoxia is increased Hct, as seen both in the wild and laboratory experiments (Fig. 1). Additionally, we see greatly elevated plasma lactate values taken from fieldcollected midshipman, suggesting increased reliance on anaerobic metabolism associated with hypoxia (Fig. 1a). This lactate elevation was confirmed in our laboratory-simulated hypoxia experiment, yet the magnitude of the response was lower than that obtained from field results. There can be several explanations for this discrepancy. It is common for field lactate concentration values to be higher than laboratory measurements, as been demonstrated in both reptiles (Bennett et al. 1981) and fish species (Scholander et al. 1962; Martin et al. 2004). The elevated lactate values seen here suggest that anaerobic metabolism may significantly contribute to the daily activity of the fish. When considering the territorial nature of the Type-I male when guarding a nest, it is plausible that field measurements represent vigorous exertion, particularly during capture, is likely fueled anaerobically. Additionally, the capture method and exertion during sampling may have resulted in higher than expected lactate levels, as it is well documented in Rainbow trout that duration of handling rapidly increases plasma cortisol, lactate, and glucose (Meka and McCormick 2005). However, our handling times were short and efforts were made to ensure caudal blood 
sampling consistently occurred within $2 \mathrm{~min}$ of capture in both males and females Nevertheless, with the significant difference between females and males morphs associated with plasma lactate and Hct, our data suggest that male Type-I midshipman are adapted for continuous bouts of hypoxia, as they have a potential for greater oxygen carrying capacity and tolerance to a build-up of plasma lactate.

Male Type-I midshipman have low oxygen consumption rates while normoxic, similar to that of other hypoxia-tolerant fish species (see Martin and Bridges 1999), and further decrease their oxygen consumption to $\sim 12 \%$ of their normoxic rate under hypoxic conditions (Fig. 4). However, a critical oxygen tension at which midshipman switch from oxyregulation to oxyconformation ( $\mathrm{P}_{\text {crit }}$; Pörtner and Grieshaber 1993) was not evident; an indication that midshipman are oxyconformers. As Scott et al. (2008) suggest, a defined $\mathrm{P}_{\text {crit }}$ is not an essential marker for hypoxia tolerance, and in the case of midshipman, being an oxyconformer may be an adaptive response to daily cycles of aquatic hypoxia. To conserve energy, it would be advantageous to conform to ambient oxygen concentrations and rapidly reduce metabolism during the initial onset of hypoxic conditions, as opposed to expending energy regulating oxygen consumption by behavioral or physiological means. In the case of the plainfin midshipman, decreased oxygen consumption (Fig. 4) and reduced ATP demand (e.g. decreased gill $\mathrm{Na}^{+} \mathrm{K}^{+}$ATPase (NKA) activity; Fig. 3) provide evidence in favor of this adaptive response, although we cannot rule out down-regulated gill enzymatic activity was due to air emergence. Active proton pumping across the plasma membrane is a major consumer of mitochondrial ATP production, where NKA consumes anywhere between $4 \%$ and $50 \%$ of basal energy production depending on the tissue examined (Clausen et al. 1991). Further examination of arterial blood gases $\left(\mathrm{O}_{2}, \mathrm{CO}_{2}\right)$ during hypoxia exposure are necessary and would assist in further elucidating the hypoxia tolerance of midshipman.

It is well established that under hypoxic conditions, tolerant fish will resort to metabolic suppression and increased reliance on anaerobic metabolism and glycolytic pathways (Hochachka et al. 1996; Guppy and Withers 1999; Bickler and Buck 2007). The present results demonstrated that male Type-I midshipman had increased plasma lactate (Fig. 1b), and changes in liver glucose and heart lactate concentrations after a 4-h aquatic hypoxic exposure (Fig. 2), although there were no statistical decreases in liver glycogen content. However, in two different Amazonian species exposed to $8 \mathrm{~h}$ of graded hypoxia, liver glycogen decreased; an indication of increased glycogenolysis (ChippariGomes et al. 2005). In relation to our study, the length of hypoxic exposure $(4 \mathrm{~h})$ may not have been long enough to produce a statistical decrease in liver glycogen content. Nevertheless, the increase in glucose in the liver is an indication of increased glycogenolysis for glucose release into the circulation, which may fuel anaerobic glycolytic pathways in other tissues; a resulting effect is the generation of lactate, as noted in both the plasma and tissues, specifically the heart. Lactate produced in these tissues under hypoxic conditions may be stored until favorable conditions return, and anaerobic byproducts metabolized. Our evidence suggests that the strategy used by parental midshipman to tolerate hypoxia is maintenance of ATP homeostasis through a combination of reduction in ATPconsuming processes (e.g. NKA activity; Fig. 3), the use of anaerobic glycolysis, and the storage of lactate.

In addition to NKA, we also measured catalase activity, an enzyme that scavenges reactive oxygen species (ROS) by decomposing reactive hydrogen peroxide to water and oxygen (Felton 1995). Generation of ROS is known to be positively correlated with ambient oxygen concentrations, where hyperoxia conditions lead to increased ROS production (Rifkind et al. 1993; Felton 1995). There are a number of animals that face the challenge of abrupt oxygen fluctuations, and most have been shown to modify their antioxidant systems in preparation for re-oxygenation by either increasing antioxidant enzyme activity or avoiding oxidative stress by reducing metabolic rate (Lushchak et al. 2001; Storey 2007). Although we do not know the status of ROS generation in the gill of midshipman in this study, we do see a significant decrease in catalase activity (Fig. 3b), suggesting a depressed metabolic rate may assist in reducing ROS formation during hypoxia, although further investigation is necessary.

The remarkable ability of the plainfin midshipman to tolerate repeated bouts of aquatic hypoxia can be attributed to their ability to rapidly suppress metabolic rate at the initial onset of hypoxic conditions, reduce ATP consumption, and tolerate a buildup of anaerobic byproducts. By examining midshipman in their natural 
environment, we have identified that Type-I males appear to have a greater tolerance of aquatic hypoxic exposure. This is likely related to the physical exertion of the Type-I males during parental care, as they remain on their nest for prolonged periods. It should be noted that this study only examined the effects of aquatic hypoxia, and does not account for other respiratory media. One possibility that is overlooked is the midshipman Type-I males breathing air as the tide recedes; we have observed several nest sites that were completely devoid of water. Survival of the midshipman in the intertidal zone may not only be attributed to tolerance of aquatic hypoxia and metabolic byproducts, but mitigated by air emergence and breathing, as demonstrated in this species by Martin (1993). Furthermore, as the midshipman eggs are retained in a thin film on the underside of rocks (Coleman 1999), they are likely exposed to air in the nest during low tide. A key selective pressure for intertidal breeding is the access to abundant oxygen and higher temperatures to accelerate growth and development (Martin and Strathman 1999). It is likely that the Type-I midshipman also takes advantage of the abundant oxygen present in the air chamber formed during low tide (personal observations). Currently, we are investigating the growth and development of the eggs under various aquatic oxygen tensions, with additional studies to compare the physiological traits aforementioned between the Type-I, -II males, and female morphs of the species to gain further evidence of the superior tolerance mechanisms of the Type-I males. The evolutionary strategies for teleost reproduction in the intertidal zone remain a fascinating topic.

\footnotetext{
Acknowledgments The authors wish to thank the staff at the Bamfield Marine Sciences Centre (BMSC) for their help and cooperation during this study. We are particularly indebted to the research coordinator Bruce Cameron for his helpful assistance. Additional thanks are extended to Carol Bucking, Karlee Craig, Risa Smith, Sue Walsh, and Tom Mommsen for the assistance in field collection of midshipman. This work was funded by a Natural Sciences and Engineering Research Council of Canada (NSERC) Discovery Grants to CMW and PJW, an NSERC Discovery Grant and an Ontario Ministry of Innovation Early Research Award to GBM, and a Canadian Society of Zoologists Student Travel Research Grant to JLF. Both JLF and PMC were recipients of NSERC postgraduate scholarships. CMW and P JW are supported by the Canada Research Chair Program. This research was approved by the Animal Care Committee at BMSC and animals were collected under permits from the Department of Fisheries and Oceans Canada.
}

\section{References}

Arora HF (1948) Observations on the habits and early life history of the batrachoid fish, Porichthys notatus Girard. Copeia 1948:89-93

Baldwin J, Wells RMG (1990) Oxygen transport potential in tropical elasmobranchs from the Great Barrier Reef: relationship between haematology and blood viscosity. J Exp Mar Biol Ecol 144:144-155

Bass AH, Bodnar D, Marchaterre MA (1999) Complementary explanations for existing phenotypes in an acoustic communication system. In: Hauser MD, Konishi M (eds) The design of animal communication. MIT University Press, pp 493-514

Bennett AF, Gleeson TT, Gorman GC (1981) Anaerobic metabolism in a lizard (Anolis bonairensis) under natural conditions. Physiol Zool 54:237-241

Bergmeyer HU (1983) Methods of enzymatic analysis. Academic, New York

Bickler PE, Buck LT (2007) Hypoxia tolerance in reptiles, amphibians, and fishes: life with variable oxygen availability. Annu Rev Physiol 69:145-170

Bradford M (1976) A rapid and sensitive method for the quantitation of microgram quantities of protein utilizing the principle of protein-dye binding. Anal Biochem 72:248254

Brantley RK, Bass AH (1994) Alternative male spawning tactics and acoustic-signals in the plainfin midshipman fish Porichthys notatus Girard (Teleostei, Batrachoididiae). Ethology 96:213-232

Brantley RK, Tseng J, Bass AH (1993) The ontogeny of interand intrasexual vocal muscle dimorphisms in a sound producing fish. Brain Behav Evol 42:336-349

Brauner CJ, Wang T (1997) The optimal oxygen equilibrium curve-a comparison between environmental hypoxia and anemia. Am Zool 37:101-108

Bridges CR (1993) Adaptation of vertebrates to the intertidal environment. In: Eduardo J, Bicudo PW (eds) The vertebrate gas transport cascade-adaptations to the environment and mode of life. CRC Press, Boca Raton, pp 12-22

Chippari-Gomes AR, Gomes LC, Lopes NP, Val AF, Almeida-Val VMF (2005) Metabolic adjustments in two Amazonian cichlids exposed to hypoxia and anoxia. Comp Biochem Physiol B 141:347-355

Clairborne A (1985) Catalase activity. In: Gunwald RA (ed) CRC handbook of methods for oxygen radical research. CRC Press, Boca Raton, pp 283-284

Clausen T, van Hardeveld C, Everts ME (1991) Significance of cation transport in control of energy metabolism and thermogenesis. Physiol Rev 71:733-774

Coleman RM (1999) Parental care in fishes. In: Horn MH, Martin KLM, Chotkowski MA (eds) Intertidal fishes: life in two worlds. Academic, New York, pp 165-180

Felton GW (1995) Oxidative stress of vertebrates and invertebrates. In: Ahmad S (ed) Oxidative stress and antioxidant defense in biology. Chapman and Hall, New York, pp 356434

Fitzpatrick JL (2008) Sperm competition in fish. Disseration, McMaster University 
Fitzpatrick JL, Craig PM, Bucking C, Balshine S, Wood CM, McClelland GB (2009) Sperm performance under hypoxic conditions in an intertidal fish (Porichthys notatus). Can J Zool 87:464-469

Guppy M, Withers P (1999) Metabolic depression in animals: physiological perspectives and biochemical generalizations. Biol Rev 74:1-40

Hastings D, Burggren W (1995) Developmental changes in oxygen consumption regulation in larvae of the South African clawed frog Xenopus laevis. J Exp Biol 198:2465-2475

Hochachka PW, Buck LT, Doll CJ, Land SC (1996) Unifying theory of hypoxia tolerance: molecular metabolic defense and rescue mechanisms for surviving oxygen lack. PNAS 93:9493-9498

Hubbs CL (1920) The bionomics of Porichthys notatus Girard. Am Nat 54:380-384

Ivancic I, Degobbis D (1984) An optimal manual procedure for ammonia analysis in natural waters by the indophenol blue method. Water Res 18:1143-1147

Lushchak VI, Lushchak LP, Mota AA, Hermes-Lima M (2001) Oxidative stress and antioxidant defenses in goldfish Carassius auratus during anoxia and reoxygenation. Am J Physiol Regul Integr Comp Physiol 280:R100-R107

Martin KLM (1993) Aerial release of $\mathrm{CO}_{2}$ and respiratory exchange ratio in intertidal fishes out of water. Environ Biol Fish 37:189-196

Martin KLM, Bridges CR (1999) Respiration in water and air. In: Horn MH, Martin KLM, Chotkowski MA (eds) Intertidal fishes: life in two worlds. Academic, New York, pp 54-78

Martin KLM, Strathman RA (1999) Aquatic organisms, terrestrial eggs: early development at the water's edge. Am Zool 39:215-217

Martin KLM, Van Winkle RC, Drais JE, Lakisic H (2004) Beach-spawning fishes, terrestrial eggs, and air breathing. Physiol Biochem Zool 77:750-759

McCormick SD (1993) Methods for the nonlethal gill biopsy and measurements of $\mathrm{Na}+, \mathrm{K}+$-ATPase activity. Can J Fish Aquat Sci 50:656-658

McDonald MD, Walsh PJ (2007) Aglomerular kidney function when challenged with exogenous $\mathrm{MgSO}_{4}$ loading or environmental $\mathrm{MgSO}_{4}$ depletion. J Exp Zool 307A:676-687

Meka JM, McCormick SD (2005) Physiological response of wild rainbow trout to angling: impact of angling duration, fish size, body condition, and temperature. Fish Res $72: 311-322$
Perry SF, Braun MH, Genz J, Vulesevic B, Taylor J, Grosell M, Gilmour KM (2010) Acid-base regulation in the plainfin midshipman (Porichthys notatus): an aglomerular marine teleost. J Comp Physiol B 180:1213-1225

Pörtner HO, Grieshaber MK (1993) Critical $\mathrm{PO}_{2}(\mathrm{~s})$ in oxyconforming and oxyregulating animals: gas exchange, metabolic rate and the mode of energy production. In: Eduardo J, Bicudo PW (eds) The vertebrate gas transport cascade: adaptations to environment and mode of life. CRC Press, Boca Raton, pp 330-357

Rahmatullah M, Boyde TR (1980) Improvements in the determination of urea using diacetyl monoxime; methods with and without deproteination. Clin Chim Acta 107:3-9

Rifkind JM, Abugo O, Levy A, Monticone R, Heim J (1993) Formation of free radicals under hypoxia. In: Hochachka PW, Lutz PL, Rosenthal M, Thillart GVD (eds) Surviving hypoxia: mechanisms of control and adaptation. CRC Press, Boca Raton, pp 509-535

Sadler J, Wells RMG, Pankhurst PM, Pankhurst NW (2000) Blood oxygen transport, rheology and hematological responses to confinement stress in diploid and triploid Atlantic salmon, Salmo salar. Aquaculture 184:349-361

Scholander PF, Bradstreet E, Garey WF (1962) Lactic acid response in the grunion. Comp Biochem Physiol 6:201-203

Scott GR, Wood CM, Sloman KA, Iftikar FI, De Boeck G, Almeida-Val VMF, Val AL (2008) Respiratory responses to progressive hypoxia in the Amazonian oscar, Astronotus ocellatus. Respir Physiol Neurobiol 162:109-116

Storey KB (2007) Anoxia tolerance in turtles: metabolic regulation and gene expression. Comp Biochem Physiol A Mol Integr Physiol 147:263-276

Thompson EM, Nafpaktitis BG, Tsuji FI (1988) Latitudinal trends in size dependence of bioluminescence in the midshipman fish Porichthys notatus. Mar Biol 98:7-13

Truchot JP, Duhamel-Jouve A (1980) Oxygen and carbon dioxide in the marine intertidal environment: diurnal and tidal changes in rockpools. Respir Physiol 39:241-254

Walker HJ Jr, Rosenblatt RH (1988) Pacific toadfishes of the genus Porichthys (Batrachoididae) with descriptions of three new species. Copeia 1988:887-904

Walsh PJ, Wang Y, Campbell CE, De Boeck G, Wood CM (2001) Patterns of nitrogenous waste excretion and gill urea transporter mRNA expression in several species of marine fish. Mar Biol 139:839-844

Yeager DP, Ultsch GR (1989) Physiological regulation and conformation: a BASIC program for the determination of critical points. Physiol Zool 62:888-907 